\title{
Circulating endothelin-3 and prolactin concentrations in healthy lactating women during the early puerperium
}

\author{
Ariadne Malamitsi-Puchner ${ }^{1}$, Ioannis E Messinis ${ }^{3}$, Vassiliki Sakellariou ${ }^{2}$, Emmanuel Economou ${ }^{2}$ \\ and Stylianos Michalas ${ }^{2}$ \\ ${ }^{2}$ First and ${ }^{1}$ Second Departments of Obstetrics and Gynecology, University of Athens, Athens, Greece and ${ }^{3}$ Department of Obstetrics and Gynecology, \\ University of Thessalia, Larissa, Greece
}

(Correspondence should be addressed to A Malamitsi-Puchner, Second Department of Obstetrics and Gynecology, University of Athens, Soultani 19, GR-10682 Athens, Greece)

\begin{abstract}
Objective: To study the association between the circulating concentrations of endothelin-3 and prolactin in the early puerperium.

Design: Prospective clinical study, including twenty-five healthy puerperal women breast-feeding their healthy full-term infants.

Methods: Venous blood was drawn on day 1 and 4 post partum, and plasma endothelin-3 and serum prolactin were determined.

Results: Circulating endothelin-3 and prolactin levels on day 4 did not differ significantly from the corresponding levels on day 1 . However, a significant negative correlation was found on day 4 between endothelin-3 and prolactin values $(r=-0.688, P<0.001)$ and an even stronger negative association existed between the net change in endothelin-3 from days 1 to 4 and the corresponding change in prolactin values $(r=-0.732, P<0.001)$.

Conclusions: On the fourth day post partum, lactating healthy women show negative correlation between circulating endothelin-3 and prolactin levels. Whether this indicates a role for endothelin-3 in the control of prolactin secretion in the post partum period remains to be clarified.
\end{abstract}

European Journal of Endocrinology 138 181-184

\section{Introduction}

Endothelins (ETs), a family of mainly three 21-amino acid peptides (ET-1, ET-2, ET-3), synthesized by three different genes in humans, are principally known for their vasoactive and mitogenic properties (1-3). However, several recent studies indicate that ETs may also participate in neuroendocrine regulation (4). In this respect, immunoreactive ET was found in the hypothalamus $(5)$ as well as in the anterior $(6,7)$ and posterior (5) pituitary gland. Moreover, it has been reported that $\left[{ }^{125} \mathrm{I}\right] \mathrm{ET}$ binds with high affinity to hypothalamic tissues (8), pituitary fragments (9) and dispersed pituitary cells (10).

Since its discovery, ET-3 has been specifically associated with the nervous tissue $(7,5,11)$. Thus it has been reported to be the major ET produced by the pituitary gland in humans (6) and rats (7). Recent studies have shown ET-3 to stimulate the release of luteinizing hormone, follicle-stimulating hormone and thyroid-stimulating hormone from primary monolayer cultures of anterior pituitary cells derived from female rats (12), as well as to exhibit a dose-dependent stimulatory effect on luteinizing hormone-releasing hormone secretion from luteinizing hormone-releasing hormone neurons in male rats (13).

On the other hand, Samson et al. (14) demonstrated that ET-3 inhibited in a specific, significant, dose-dependent and reversible fashion prolactin (PRL) release from cultured anterior pituitary cells. In addition, Kanyicska et al. (12) provided further evidence for the concentration-dependent decrease of PRL secretion from pituitary cell cultures elicited by ET-3. Nevertheless, the former authors claim in another study that ET-3 also exerts transient stimulatory effects on PRL release in rats (15).

So far, no data exist concerning the relationship between circulating ET-3 and PRL concentrations in various conditions in vivo, particularly in humans. The present study was based on the hypothesis that ET-3 may be implicated in PRL release in puerperal women. We investigated the association of blood concentrations of ET-3 and PRL on the first and fourth day after delivery in healthy women.

\section{Materials and methods}

The study was approved by the ethics committee of our teaching hospital. Twenty-five healthy post partum 
women aged (mean \pm s.E.M.) $27.6 \pm 1.1$ years were included after giving informed consent. All the women studied were non-smokers, did not drink alcohol and had had an uneventful pregnancy. They all delivered vaginally, without any complication, healthy full-term infants (13 boys, 12 girls, gestational age and birthweight (mean \pm s.E.M.) $39.1 \pm 0.2$ weeks and $3165 \pm$ $107 \mathrm{~g}$ respectively). All were breastfeeding their infants for 10 min eight times a day and were not receiving any medication. On the first and fourth day post partum, around noon, $2 \mathrm{~h}$ after the last breastfeed, $10 \mathrm{ml}$ venous blood were drawn for determination of serum PRL and plasma ET-3 concentrations.

Serum PRL was measured by a microparticle enzyme immunoassay using the relevant IMx Prolactin assay kit (Abbott Laboratories Diagnostics Division, Abbott Park, IL, USA). The minimum detectable dose of the assay was $\leq 0.6 \mathrm{ng} / \mathrm{ml}$. Intra-assay coefficient of variation $(\mathrm{CV})$ was $3.43 \%$ and interassay CV $4.86 \%$. The results are expressed in $\mathrm{ng} / \mathrm{ml}$.

For the measurement of plasma ET-3 levels the peptide was first extracted from plasma by affinity chromatography using $200 \mathrm{mg} \mathrm{C}_{18}$ SEP columns (Cat No: RIK-SEPCOL1, Peninsula Laboratories, Belmont, CA, USA). The extraction procedure was as follows. In a plasma volume of $5 \mathrm{ml}$ an equal amount of solution A $(0.1 \%$ trifluoroacetic acid) was added. The solution was vortexed thoroughly and centrifuged at $9000 \mathrm{~g}$ for $20 \mathrm{~min}$ at $4^{\circ} \mathrm{C}$. Each SEP column was equilibrated by washing once with $1 \mathrm{ml}$ solution B $(60 \%$ acetonitrile in $0.1 \%$ trifluoroacetic acid), followed by $3 \times 3 \mathrm{ml}$ solution A. Then each plasma solution, divided into two equal parts, was loaded on to corresponding pretreated SEP columns. Each column was washed slowly with $2 \times 3 \mathrm{ml}$ solution $\mathrm{A}$ and the wash was discarded. Finally, ET-3 was slowly eluted with $3 \mathrm{ml}$ solution B, and the eluate collected in a corresponding polypropylene tube. Eluates derived from the same plasma solution were combined and evaporated to dryness under a stream of nitrogen. The residue was dissolved in $250 \mu \mathrm{l}$ RIA buffer for a two-tube assay and was measured by RIA using the relevant Peninsula ET-3 RIA kit (Peninsula Laboratories, Belmont, CA, USA). The minimum detectable dose of ET-3 was determined by adding two standard deviations to the mean c.p.m. value of 20 zero-standard replicates and by calculating the corresponding concentration from the standard curve. This was found to be $0.12 \mathrm{pg} / \mathrm{tube}$, equivalent to $0.12 \mathrm{pg}$ per plasma volume $(5 \mathrm{ml})$ used for extraction. Intra-assay CV was $4.7 \%$ and interassay CV $9.8 \%$. The percentage cross-reactivity of the anti-ET-3 antibody used in this assay was 0.1 with ET-1, 0.1 with ET-2 and 0.2 with big ET-1, while no cross-reactivity was observed with big endothelin 22-38. The results are expressed in $\mathrm{pg} / \mathrm{ml}$.

Statistical analysis was by the Wilcoxon test for paired differences and Spearman rank correlation coefficient test.

\section{Results}

Plasma ET-3 and serum PRL values (mean \pm S.E.M.) on day 4 post partum $(2.95 \pm 0.4 \mathrm{pg} / \mathrm{ml}$, range $0.4-9.2 \mathrm{pg} / \mathrm{ml}$, and $238 \pm 21 \mathrm{ng} / \mathrm{ml}$, range $15-489 \mathrm{ng} / \mathrm{ml}$ respectively) were similar to those on day $1(3.16 \pm 0.5 \mathrm{pg} / \mathrm{ml}$, range $0.18-9.8 \mathrm{pg} / \mathrm{ml}$, and $212 \pm 19 \mathrm{ng} / \mathrm{ml}$, range $76-$ $393 \mathrm{ng} / \mathrm{ml}$ respectively). A significant negative correlation was found on day 4 between ET-3 and PRL values $(r=-0.688, P<0.001)$ (Fig. 1a). The inverse association was stronger and statistically highly significant when the difference between ET-3 levels on day 1 and day 4 was correlated with the corresponding difference in PRL values preserving algebraic notation, Spearman's $r$ then being equal to $-0.732, P<0.001$. A negative correlation between ET-3 and PRL values was also found on day 1 , but compared with day 4 this correlation was not significant, probably because of the small number of cases $(r=-0.333, P=0.09)$ (Fig. 1b). There was no significant correlation between ET-3 or PRL levels and the birthweight of the neonates. Also, the levels of ET-3 and PRL on either day 1 or 4 did not differ significantly between the women who delivered male or female neonates.
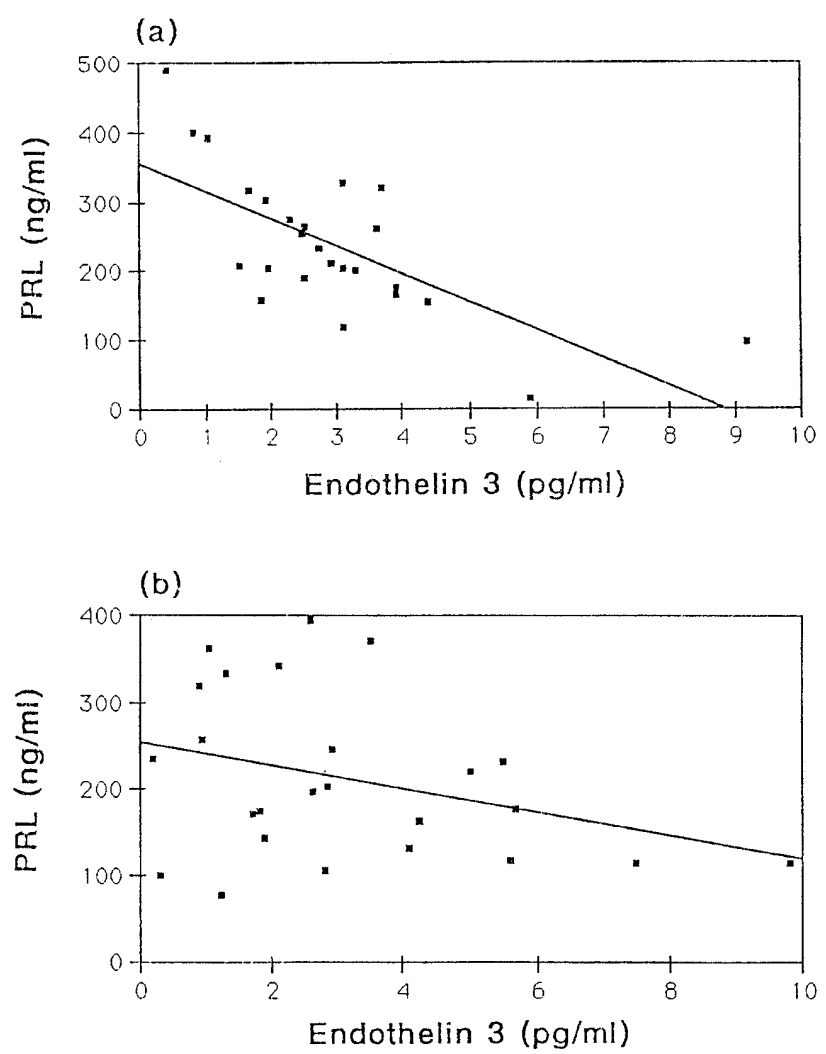

Figure 1 Correlation between plasma ET-3 and serum PRL levels in puerperal women on (a) day 4 and (b) day 1 after delivery. 


\section{Discussion}

This study presents for the first time levels of ET-3 in the peripheral circulation of normal women during the immediate post partum period. The values remained unchanged from days 1 to 4 after delivery and so did the levels of PRL.

The origin of ET-3 in the peripheral circulation of pregnant women and in the post partum period is unclear. A possible source could be the placenta, as recent evidence has demonstrated the expression of the ET-3 gene in the human placenta $(16,17)$. However, this assumption requires further investigation. On the other hand, it has been suggested that ET-3 is mainly derived from the nervous tissue, as it is apparently the most abundant form of ET in the hypothalamo-hypophysial system (15). However, it cannot be completely excluded that ET produced in the anterior pituitary may act as a circulating hormone (18).

The present study demonstrates significant correlations between circulating post partum levels of ET-3 and PRL. In particular, ET-3 levels on day 4 after delivery were inversely related to serum PRL, but the correlation was even stronger between the net change in ET-3 from days 1 to 4 and the corresponding change in PRL values. Since PRL in the circulation of puerperal women is derived from the pituitary lactotrophs, it is tempting to speculate that ET-3 may exert an effect on PRL secretion from the anterior pituitary. However, these results cannot exclude the opposite possibility, that PRL affects ET-3 secretion, or even that the production of these two substances is regulated by another agent. Furthermore, it should be noted that the present study was restricted to the first and fourth day post partum and therefore conclusions about the relationship of ET-3 and PRL over a longer period of time cannot be drawn.

Previous studies have raised doubts about a possible effect of ETs in the peripheral circulation on the secretion of anterior pituitary hormones, since even doses that cause severe vasoconstriction and elevation of blood pressure were ineffective in suppressing PRL release (15). Also, it has been claimed that ETs produced in the brain do not act centrally to affect the release of trophic factors controlling PRL secretion (15). However, a study in normal men has shown that the intravenous injection of ET-1, although not affecting basal PRL levels, suppressed significantly thyroid releasing hormone-induced PRL secretion (19). The present preliminary data showing correlations between ET-3 and PRL levels could provide some evidence that circulating ET-3 after delivery may affect central PRL secretion in women. On the other hand, it could be possible that ET-3 derived from the nervous tissue acts locally and that peripheral plasma levels only reflect the central production.

One should take into account that the women included in this study were lactating and this may explain the unchanged levels of PRL from days 1 to 4 post partum, which otherwise might decline. Since PRL secretion increases markedly during suckling (20), in the present study precautions were taken to avoid blood sampling too close to the suckling periods; in all the women, the samples were taken around noon, $2 \mathrm{~h}$ after a suckling event, which had lasted for $10 \mathrm{~min}$.

The mechanism by which ET-3 may affect PRL secretion from the pituitary is not known. Although in vitro data have shown that ET-1 and ET-3 inhibit basal and stimulated release of PRL by human decidual cells (21), circulating PRL during pregnancy and the post partum period is derived from the pituitary. In vitro data have shown that exposure of anterior pituitary cells to a sustained effect of dopamine reverses the inhibitory effect of ET-1 on PRL secretion (22), indicating that this type of ET at least may affect PRL secretion by antagonizing dopamine activity. However, the mechanism of the ET-3-controlling effect on PRL secretion remains to be clarified.

In conclusion, these preliminary data demonstrate a negative correlation between circulating ET-3 and PRL levels in lactating women on the fourth day after delivery. Whether this indicates a role for ET-3 in the control of PRL secretion in the post partum period remains to be clarified.

\section{References}

1 Janagisawa M, Kurihara H, Kimura S, Tomobe Y, Kobayashi M, Mitsui Y et al. A novel potent constrictor peptide produced by vascular endothelial cells. Nature 1988332 411-415.

2 Hirata Y, Takagi Y, Fukuda Y \& Marumo F. Endothelin is a potent mitogen for rat vascular smooth muscle cells. Atherosclerosis $198978225-228$.

3 Simonson MS, Wann S, Mene P, Dubyak GR, Kester M, Nakazato Y et al. Endothelin stimulates phospholipase $\mathrm{C}, \mathrm{Na}^{+} / \mathrm{H}^{+}$exchange, $\mathrm{C}$-fos expression and mitogenesis in rat mesangial cells. Journal of Clinical Investigation 198983 708-712.

4 Stojilkovic SS, Balla T, Fukuda S, Cesnjaj M, Merelli F, Krsmanovic LZ et al. Endothelin $\mathrm{ET}_{\mathrm{A}}$ receptors mediate the signaling and secretory actions of endothelins in pituitary gonadotrophs. Endocrinology $1992130465-474$

5 Yoshizawa T, Shinmi O, Giaid A, Yanagisawa M, Gibson SJ, Kimura S et al. Endothelin: a novel peptide in the posterior pituitary system. Science $1990247462-464$.

6 Takahashi K, Ghatei MA, Jones PM, Murphy JK, Lam H-C, O'Halloran $\mathrm{J}$ et al. Endothelin in human brain and pituitary gland: presence of immunoreactive endothelin, endothelin messenger ribonucleic acid and endothelin receptors. Journal of Clinical Endocrinology and Metabolism 199172 693-699.

7 Matsumoto H, Suzuki N, Onda H \& Fujino M. Abundance of endothelin-3 in rat intestine, pituitary gland and brain. Biochemical and Biophysical Research Communications 1989164 74-80.

8 Krsmanovic LZ \& Al Damluji S. Endothelin stimulates inositol phosphate breakdown and GnRH secretion in cultured hypothalamic cells. 73rd Annual Meeting of the Endocrine Society, Washington DC 1991. Abstract 1604.

9 Calvo JJ, Gonzalez R, Freire de Carvalho L, Takahashi K, Kanse SM, Hart GR et al. Release of substance P from rat hypothalamus and pituitary by endothelin. Endocrinology 1990126 2288-2295.

10 Stojilkovic SS, Merelli F, Iida T, Krsmanovic LZ \& Catt KJ. Endothelin stimulation of cytosolic calcium and gonadotropin secretion in anterior pituitary cells. Science 1990248 1663-1666. 
11 Shinmi O, Kimura S, Sawamura T, Sugita Y, Yoshizawa T, Uchiyama Y et al. Endothelin-3 is a novel neuropeptide: isolation and sequence determination of endothelin-1 and endothelin-3 in porcine brain. Biochemical and Biophysical Research Communications $1989164587-593$.

12 Kanyicska B, Burris TP \& Freeman ME. Endothelin-3 inhibits prolactin and stimulates $\mathrm{LH}, \mathrm{FSH}$, and TSH secretion from pituitary cell culture. Biochemical and Biophysical Research Communications $1991174338-343$.

13 Moretto M, Lopez FJ \& Negro-Vilar A. Endothelin-3 stimulates luteinizing hormone-releasing hormone (LHRH) secretion from LHRH neurons by a prostaglandin-dependent mechanism. Endocrinology 1993132 789-794.

14 Samson WK, Skala KD, Alexander BD \& Huang FL. Pituitary site of action of endothelin: selective inhibition of prolactin release in vitro. Biochemical and Biophysical Research Communications 1990 $169737-743$.

15 Samson WK, Skala KD, Alexander B \& Huang FLS. Possible neuroendocrine actions of endothelin-3. Endocrinology 1991128 1465-1473.

16 Onda H, Ohkubo S, Ogi K, Kosaka T, Kimura C, Matsumoto H et al. One of the endothelin gene family, endothelin-3 is expressed in the placenta. FEBS Letters $1990261327-330$.

17 Mitchell MD. Endothelins in perinatal biology. Seminars in Perinatology $19911579-85$.
18 Naruse M, Naruse K, Nishikawa T, Yoshihara I, Ohsumi K, Suzuki $\mathrm{N}$ et al. Endothelin-3 immunoreactivity in gonadotrophs of the human anterior pituitary. Journal of Clinical Endocrinology and Metabolism 199274 968-972.

19 Vierhapper H, Hollenstein U, Roden M \& Nowotny P. Effect of endothelin-1 in man: impact on basal and stimulated concentrations of luteinizing hormone, follicle-stimulating hormone, thyrotropin, growth hormone, corticotropin and prolactin. Metabolism 199342 902-906.

20 Yokoyama Y, Ueda T, Irahara M \& Aono T. Release of oxytocin and prolactin during breast massage and suckling in puerperal women. European Journal of Obstetrics Gynecology and Reproductive Biology 199453 17-20.

21 Chao HS, Myers SE \& Handwerger S. Endothelin inhibits basal and stimulated release of prolactin by human decidual cells. Endocrinology 1993133 505-510.

22 Kanyicska B, Livingstone JD \& Freeman ME. Long term exposure to dopamine reverses the inhibitory effect of endothelin-1 on prolactin secretion. Endocrinology $1995136990-$ 994.

Received 25 August 1997

Accepted 7 October 1997 